\title{
Contraceptive Methods: The Level of Awareness and Patronage among Ghanaian Health Profession Trainees
}

\author{
Evans Paul Kwame Ameade ${ }^{1 *}$ and Saeed Folorunsho Majeed $^{2}$ \\ ${ }^{1}$ Department of Pharmacology, School of Medicine and Health Sciences, University for Development Studies, Tamale \\ ${ }^{2}$ Department of Physiology and Biophysics, School of Medicine and Health Sciences, University for Development Studies, Tamale
}

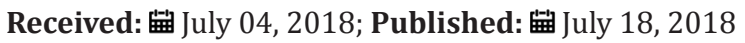

*Corresponding author: Evans Paul Kwame Ameade, Department of Pharmacology, School of Medicine and Health Sciences, PO.Box TL 1350, Tamale

\section{Abstract}

Introduction: Health workers are invaluable human resources that ensure the unmet contraceptive needs of especially people in developing countries are bridged. Even before their graduation, health profession trainees would be looked up to by society to provide services on contraceptive use. This study therefore assessed their level of awareness and patronage of contraceptive methods among health profession trainees.

Methodology: Graph Pad 5.01 and SPSS 21.0 software (SPSS Inc, Chicago, IL) were used to analyze data collected from 376 randomly selected university students in Tamale, Ghana in a cross-sectional study using a semi-structured questionnaire. Association between different variables was tested using appropriate statistical tests.

Results: Health profession students were more aware of female contraceptive methods than that of the males. The condom was the most listed and used male contraceptive while the oral contraceptive was the best known female contraceptive among the respondents but the emergency contraceptive, Levonorgestrel branded Postinor 2 was the most used female contraceptive. Advancing biological age, marital status and programme of study were significantly associated with students' level of awareness of contraceptive methods but multivariate analysis showed that after adjustment, being a male student (OR=1.95; 95\% CI, $1.04-3.67 ; \mathrm{p}=0.037)$ and being married (OR = 10.48; 95\% CI, $4.81-56.49 ; \mathrm{p}<0.0001)$ were significantly associated with contraceptive use.

Conclusion: Older age, programme of study and marital status of health profession trainees were significantly associated with better awareness of contraceptive methods. The predictors of the use of contraceptives were being a male and being married

Keywords: Contraceptive Methods; Health Profession; Students; Ghana

Abbreviations: UNPD: United Nations' Department of Economic and Social Affairs - Population Division; NPC: National Population Council; GHDS Ghana Health and Demographic Survey

\section{Introduction}

Increaseduse of contraceptives across theworld had safeguarded the health of sexually active females since significant numbers of unintended pregnancies and subsequent abortions related deaths have been averted [1-6]. Contraception had also led to improvement of perinatal outcomes by a reduction in the number of babies born premature, low birth-weight or small for their gestational age thereby resulting in a reduction in infant mortality [7]. Other noncontraception importance of contraceptives includes a reduction of gynaecological cancers, menstruation related symptoms and disorders, sexually transmitted infections and improvement of socio-economic status of women $[2,6]$. According to the United Nations' Department of Economic and Social Affairs - Population Division (UNPD)'s 2013 report, whereas global contraceptive prevalence is estimated at 63 percent, and more developed regions recording 72 per cent, majority of less developed regions scored 50 per cent or less [8]. Even worse are sub-Saharan African countries reporting exceptionally low contraceptive prevalence of below 30 percent among married or unmarried women between ages 15 and 49 [8]. High population growth rate as a result of low contraceptive use in poor developing countries is exerting severe social, economic and environmental pressures on the citizenry which invariably affects their health and wellbeing $[6,9]$.

High contraceptive prevalence rate had contributed to the low birth rates recorded in developed countries so for developing countries who desire to have rapid economic growth, there would be the need for them to embark on strategies to encourage voluntary contraceptive use so as to reduce the high unmet needs for contraception [4,9]. Ghana's National Population Council (NPC)'s population stabilization 2011 report indicated that Ghana's population at the last census in 2010 was 24.2 million and with a population growth rate of 2.4 percent, the population would double by the year 2040 [10]. Like other sub-Saharan Africa countries, Ghana's population structure is predominantly youthful, who are the most fertile class, hence there is a threat to the country's future 
economic progress and development if greater efforts are not put in place to delay first sexual encounter and increase contraceptive use among the youth. The youthful and fertile section of the Ghanaian population need be encouraged to use contraceptives to reduce this high birth rate. In most sub-Saharan Africa countries, the most stated reasons for not using contraceptive has been the lack of knowledge about contraception, health concerns in relation to the side effects [11-13] as well as restrictive and unfriendly attitude of health providers [14].

First to be contacted by persons who wish to practice contraception are the health workers hence they must possess good knowledge on contraception to ensure they provide would-be users accurate information and also exhibit attitudes which will make acquisition, and continued usage of contraceptives more attractive. A study in Bangladesh by [15] showed that a health worker's quality of care increased the likelihood of a woman starting contraception and not discontinuing [15]. Ghana's low contraceptive prevalence rate of $25.6 \%$ and an unmet contraception gap of $35.3 \%$ require that policy makers revise their methods of providing contraception to the population and adopt strategies that would ensure growth rate is reduced [16]. The health worker is therefore indispensable in the quest of a country to bridge that unmet contraception gap. Several studies have been conducted in Ghana among secondary school and university students which assessed students' knowledge, attitude and use of contraceptives but there is no reported study among health profession trainees. The schools of Medicine and Health Sciences as well as Allied Health Sciences of the University for Development Studies in Tamale, Ghana, trains students who in the future would become doctors, nurses, midwives, health educators, as well as nutritionists; professionals who have roles in serving the contraception needs of Ghanaians through provision of accurate knowledge and counseling services. This study therefore assessed health profession trainees' level of awareness of the various contraceptive methods, their level patronage as well as factors that influenced their awareness and patronage levels of the various contraceptives methods.

\section{Methods}

\section{Study Design and Setting}

Data on the awareness and level of use of contraceptives among undergraduate students of the schools of Medicine and Health Sciences and Allied Health Sciences of the University for Development Studies was obtained through a cross sectional survey between March and April, 2015. The study programmes of the students were Medicine, Nursing, Midwifery, Health Science Education and Community Nutrition. Data was collected with a semi-structured questionnaire which was pretested among 20 students which ensured correction of ambiguous and inconsistent questions before it was administered for the actual data collection.

\section{Study Variable Measurements}

Level of awareness of the participants on contraceptive methods was measured by asking respondents who answered in the affirmative to knowing of male and female contraceptive methods to list three of these methods. Ability to list a correct male or female contraceptive method scored a mark. A maximum score of three (3) was awarded for being aware of male or female contraceptive methods.

\section{Ethical Consideration}

Prior approval for this study and the procedures were obtained from the Ethics Committee of the School of Medicine and Health Sciences of the University for Development Studies. Data was collected from participants only after they had verbally given a free and informed consent to take part in the study.

\section{Study Sample Size Determination}

With the study population of students being 2029, the required return sample size without estimated response rate factor $n_{1}$ (323) was calculated using the Cochran's correction formula for categorical data;

$$
n_{1}=\frac{n_{0}}{1+\frac{n_{0}}{\text { population }}},
$$

$\mathrm{n}_{0}$ the required sample size (384) was calculated using the formula $n_{0}=\frac{t^{2}(p)(1-p)}{d^{2}}$ based on the assumption that $50 \%$ of respondents possess good awareness level of contraception and also use contraceptives ( $\mathrm{p}=0.5$ ), sampling error (d) being $5 \%$ (0.05), confidence interval of $95 \%$, and normal distribution value (t) at a significant alpha level of 0.05 being 1.96. With an estimated response rate of $70 \%$, a drawn sample size of $461\left(\frac{n_{1}}{0.7}\right)$ was considered for this study.

\section{Sampling Procedure}

The number of respondents from any class in study programmes of Nursing, Midwifery, Community Nutrition, Health Science Education and Medicine was obtained using a proportionate sampling approach. In each class, the required number of respondents was randomly chosen from an envelope, containing pieces of paper which has the names and identity number of all members of the class printed on it. The respondents were drawn using the sampling with replacement method.

\section{Statistical Analysis}

Data was entered into Microsoft Excel, and analyzed using Graph Pad Prism, Version 5.01 (GraphPad Software Inc., San Diego CA). Associations between respondents' socio-demographic characteristics and their level of awareness of male and female contraceptive methods were assessed using the One-way ANOVA test. Independent t-test was used to assess the influence that sociodemographic characteristics of the respondents have on their usage of contraceptive methods. Statistical significance was assumed at $\mathrm{p}$ $<0.05$ and at a confidence interval of $95 \%$.

\section{Results}

The response rate for this study was $81.6 \%(n=376 / 461)$ (Table 1) provides information on the socio-demographic characteristics of the respondents sampled. Majority of respondents, 288 (76.6\%) were between the ages of 20 and 25; were males, 189 (50.3\%) and belong to the Christian faith, 251 (66.8\%). Most, 129 (34.3\%) of the respondents grew up in the cities of Ghana and were pursuing the Bachelor degree in nursing programme, 118 (31.4\%). Although 
most, 182 (48.4\%) of respondents were single and not in any form of relationship at the time of the study, a majority, 368 (97.9\%) were desirous of marrying in the future with most, 133 (37.4\%) intending to have a maximum of four children. Insert (Table 1) with in the period of one year preceding the study, 69 (33.7\%) of all the respondents were married, in a relationship or single but users of contraceptives, had used at least one form of contraception. Majority of respondents who had used a contraceptive method, 37 (54.3\%) were male students.

Table 1: Socio-demographic characteristics of the respondents.

\begin{tabular}{|c|c|c|c|}
\hline Variable & Subgroup & $\begin{array}{c}\text { Number of } \\
\text { Respondents }\end{array}$ & Percentage* \\
\hline \multirow[t]{3}{*}{ Age range } & $<20$ & 37 & 9.8 \\
\hline & $20-25$ & 288 & 76.6 \\
\hline & $>25$ & 51 & 13.5 \\
\hline \multirow[t]{2}{*}{ Sex } & Male & 189 & 50.3 \\
\hline & Female & 187 & 49.7 \\
\hline \multirow[t]{5}{*}{ Programme of study } & $\begin{array}{l}\text { Community } \\
\text { Nutrition }\end{array}$ & 78 & 20.7 \\
\hline & $\begin{array}{l}\text { Health Science } \\
\text { Education }\end{array}$ & 56 & 14.9 \\
\hline & Midwifery & 33 & 8.8 \\
\hline & Nursing & 118 & 31.4 \\
\hline & Medicine & 91 & 24.2 \\
\hline \multirow[t]{3}{*}{ Religious affiliation } & Islam & 123 & 32.7 \\
\hline & Christianity & 251 & 66.8 \\
\hline & Others & 2 & 0.5 \\
\hline \multirow{5}{*}{$\begin{array}{c}\text { Where you grew up } \\
\text { between ages } 6 \text { and } \\
15 \text { years }\end{array}$} & City & 129 & 34.3 \\
\hline & Regional capital & 45 & 12.0 \\
\hline & Towns & 75 & 19.9 \\
\hline & District capitals & 63 & 16.8 \\
\hline & Villages & 64 & 17.0 \\
\hline \multirow[t]{3}{*}{ Relationship } & $\begin{array}{l}\text { Single (No } \\
\text { relationship) }\end{array}$ & 182 & 48.4 \\
\hline & $\begin{array}{l}\text { Single (In } \\
\text { relationship) }\end{array}$ & 158 & 42.0 \\
\hline & Married & 35 & 9.3 \\
\hline \multirow[t]{2}{*}{$\begin{array}{l}\text { Married or wish to } \\
\text { marry? }\end{array}$} & Yes & 368 & 97.9 \\
\hline & No & 6 & 1.6 \\
\hline \multirow[t]{5}{*}{$\begin{array}{c}\text { If intend to have } \\
\text { children, maximum } \\
\text { number wished for } \\
\quad(n=356)\end{array}$} & 1 & 1 & 0.3 \\
\hline & 2 & 23 & 6.5 \\
\hline & 3 & 130 & 36.5 \\
\hline & 4 & 133 & 37.4 \\
\hline & $>4$ & 69 & 19.4 \\
\hline
\end{tabular}

*Percentage less than 100 percent due to missing values.
Table 2: Level of usage of contraceptives among respondents

\begin{tabular}{|c|c|c|c|}
\hline Variable & Subgroup & Number & Percentage \\
\hline $\begin{array}{c}\text { Ever used a contraceptive } \\
\text { within a year?* }(\mathrm{n}=205)\end{array}$ & Yes & 69 & 33.7 \\
\hline & No & 136 & 66.3 \\
\hline $\begin{array}{c}\text { Users of contraceptives (n } \\
\text { = 59) }\end{array}$ & Males & 37 & 53.6 \\
\hline & Females & 32 & 46.4 \\
\hline Male contraceptives used & Condom & 32 & 86.5 \\
\hline & Others & 5 & 13.5 \\
\hline Female contraceptives used & Condom & 7 & 21.9 \\
\hline & Injectables & 6 & 18.8 \\
\hline & IUD & 2 & 6.3 \\
\hline & $\begin{array}{c}\text { Oral } \\
\text { pormonal }\end{array}$ & 6 & 18.8 \\
\hline & Postinor 2 & 10 & 31.3 \\
\hline & Primolut N & 1 & 3.1 \\
\hline
\end{tabular}

*The $\mathrm{n}=205$ is made up of respondents who were married or in a relationship as well as 12 who used contraceptive although they were not currently in a relationship.

Table 3: Respondents' level of awareness of male and female contraceptive methods.

\begin{tabular}{|c|c|c|c|}
\hline Statement & Subgroup & $\begin{array}{l}\text { Number of } \\
\text { respondents }\end{array}$ & Percentage \\
\hline \multirow{2}{*}{$\begin{array}{l}\text { Know any male } \\
\text { contraceptive } \\
\text { method? }\end{array}$} & Yes & 283 & 75.3 \\
\hline & No & 93 & 24.7 \\
\hline \multirow{4}{*}{$\begin{array}{c}\text { Listing } 3 \text { male } \\
\text { contraceptive } \\
\text { methods }(n=283)\end{array}$} & None correct & 7 & 2.5 \\
\hline & One correct & 52 & 18.4 \\
\hline & Two correct & 107 & 37.8 \\
\hline & All three correct & 117 & 41.3 \\
\hline \multirow[t]{3}{*}{$\begin{array}{l}\text { Male contraceptive } \\
\text { methods listed }\end{array}$} & Vasectomy & 220 & 77.7 \\
\hline & Condom & 242 & 85.5 \\
\hline & $\begin{array}{l}\text { Coitus } \\
\text { interruptus }\end{array}$ & 155 & 54.8 \\
\hline \multirow{2}{*}{$\begin{array}{l}\text { Know any female } \\
\text { contraceptive } \\
\text { method? }\end{array}$} & Yes & 298 & 79.3 \\
\hline & No & 78 & 20.7 \\
\hline \multirow{4}{*}{$\begin{array}{c}\text { List } 3 \text { female } \\
\text { contraceptive } \\
\text { methods }(n=298)\end{array}$} & None correct & 5 & 1.7 \\
\hline & One correct & 29 & 9.7 \\
\hline & Two correct & 81 & 27.2 \\
\hline & All three correct & 183 & 61.4 \\
\hline \multirow[t]{2}{*}{$\begin{array}{l}\text { Female contraceptive } \\
\text { methods listed }\end{array}$} & Tubal ligation & 75 & 25.2 \\
\hline & Spermicides & 23 & 7.7 \\
\hline
\end{tabular}




\begin{tabular}{|l|c|c|c|}
\hline & $\begin{array}{c}\text { Oral } \\
\text { contraceptives }\end{array}$ & 183 & 61.4 \\
\hline & LAM $^{*}$ & 9 & 3.0 \\
\hline & IUD & 92 & 30.9 \\
\hline & Injectables & 71 & 23.8 \\
\hline & $\begin{array}{c}\text { Implants } \\
\text { Fertility } \\
\text { Based methods }\end{array}$ & 59 & 19.8 \\
\hline & $\begin{array}{c}\text { Emergency oral } \\
\text { contraceptives }\end{array}$ & 13 & 14.8 \\
\hline & $\begin{array}{c}\text { Diaphragm } \\
\text { Condoms }\end{array}$ & 8 & 2.7 \\
\hline & $\begin{array}{c}\text { Others (Skin } \\
\text { patch, sponge, } \\
\text { cervical caps) }\end{array}$ & 5 & 53.7 \\
\hline
\end{tabular}

*Lactational Amenorrhoea Method **Percentages calculated based on total number of respondents $(n=376)$

Whereas the most common male contraceptive used was the condom, 32 (86.5\%), the emergency contraceptive containing
Levonorgestrel branded Postinor -2 was the contraceptive agent used by most of the females in this study, 10 (31.3\%). Other more commonly used contraceptives used by female respondents in this study were condoms, 7 (21.9\%), injectables, 6 (18.8\%) and hormonal pills, 6 (18.8\%). The level of usage of contraceptives and the types commonly used by respondents are shown in (Table 2). Majority of respondents had heard of both male, 283 (75.3\%) and female, 298 (79.3\%) contraceptive methods. The number of respondents who accurately listed three types of female contraceptive was more than the number who were able to list three male contraceptives (61.4\% vrs $41.3 \%$ ). Condom was the most listed male contraceptive (85.5\%) while oral contraceptives was the most common female contraception method stated (Table 3 ) shows the level of awareness of respondents on both the male and female contraceptive methods (Table 4) shows the association between respondents' level of awareness about contraceptives and their socio-demographic characteristics. Respondents who were aged more than 25 years exhibited significantly better aware about both male (2.522 vrs $2.186-1.555 ; \mathrm{p}<0.0001)$ and female contraceptive methods ( 2.745 vrs $2.482-2.037 ; p=0.003$ ) than their younger colleagues.

Table 4: Relationship between the socio-demographic characteristics of respondents and their level of awareness of contraceptive methods.

\begin{tabular}{|c|c|c|c|c|c|}
\hline \multicolumn{6}{|c|}{ Awareness of contraceptive methods } \\
\hline & & Male methods & & Female methods & \\
\hline Demographic characteristics & Variable & Awareness score & p-value & Awareness score & p-value \\
\hline \multirow[t]{3}{*}{ Age range } & $<20$ & $1.556 \pm 0.698$ & $<0.0001^{*}$ & $2.037 \pm 1.018$ & $0.0003^{*}$ \\
\hline & $20-25$ & $2.186 \pm 0.806$ & & $2.482 \pm 0.744$ & \\
\hline & $>25$ & $2.522 \pm 0.722$ & & $2.745 \pm 0.570$ & \\
\hline \multirow[t]{2}{*}{ Sex } & Male & $2.136 \pm 0.816$ & 0.345 & $2.457 \pm 0.736$ & 0.564 \\
\hline & Female & $2.227 \pm 0.816$ & & $2.506 \pm 0.744$ & \\
\hline \multirow[t]{5}{*}{ Programme of study } & Community Nutrition & $1.956 \pm 0.878$ & $0.006^{*}$ & $2.111 \pm 0.925$ & $0.0006^{*}$ \\
\hline & Health Science Education & $2.293 \pm 0.68$ & & $2.512 \pm 0.703$ & \\
\hline & Midwifery & $2.6 \pm 0.707$ & & $2.742 \pm 0.576$ & \\
\hline & Nursing & $2.248 \pm 0.817$ & & $2.573 \pm 0.677$ & \\
\hline & Medicine & $2.014 \pm 0.819$ & & $2.514 \pm 0.667$ & \\
\hline \multirow[t]{2}{*}{ Religious affiliation } & Islam & $2.170 \pm 0.757$ & 0.837 & $2.521 \pm 0.729$ & 0.547 \\
\hline & Christianity & $2.191 \pm 0.844$ & & $2.466 \pm 0.745$ & \\
\hline \multirow[t]{3}{*}{ Relationship* } & Single (No relationship) & $2.070 \pm 0.815$ & $0.002^{*}$ & $2.410 \pm 0.748$ & $0.036^{*}$ \\
\hline & Single (In relationship) & $2.175 \pm 0.847$ & & $2.477 \pm 0.763$ & \\
\hline & Married & $2.618 \pm 0.551$ & & $2.771 \pm 0.547$ & \\
\hline \multirow[t]{5}{*}{ Where you grew up between ages 6 and 15 years } & City & $2.090 \pm 0.818$ & 0.590 & $2.447 \pm 0.764$ & 0.354 \\
\hline & Regional capital & $2.103 \pm 0.939$ & & $2.6 \pm 0.651$ & \\
\hline & Towns & $2.255 \pm 0.821$ & & $2.411 \pm 0.733$ & \\
\hline & District capitals & $2.280 \pm 0.784$ & & $2.630 \pm 0.735$ & \\
\hline & Village & $2.224 \pm 0.771$ & & $2.4 \pm 0.756$ & \\
\hline
\end{tabular}

*Statistically significant

Female respondents were more aware of both male $(2.227$ vrs 2.136$)$ and female (2.506 vrs 2.457 ) contraceptive methods than the males but the differences were not significant. Religious affiliation and locality where the respondents grew up showed no association with their awareness level on both male and female contraceptive methods. The programme of study and the marital status of respondents however was significantly associated with respondents' awareness level of both male and female contraceptive 
methods. Students from the midwifery class exhibited the highest awareness for male (2.6 vrs 2.293 to $1.956 ; \mathrm{p}=0.006$ ) and female (2.742 vrs 2.573 to $2.111 ; p=0.0006)$ contraceptive methods. Again more married respondents than the unmarried had better and significant awareness of both male (2.618 vrs 2.175 to 2.070; $\mathrm{p}=0.002$ ) and female (2.771 vrs 2.477 to $2.410 ; \mathrm{p}=0.036$ ) contraceptive methods. Sex and religion were not associated with the usage of contraceptives although more male respondents (19.6\% vrs $17.1 \%$ ) and followers of Christianity (19.1\% vrs $17.1 \%$ ) use contraceptives than their female and Moslem colleagues.
Respondents who grew up in rural areas significantly used a lot more contraceptives than their colleagues from urban areas $(32.3 \%$ vrs $18.0 \% ; p=0.33$ ) but the difference was not significant. In this study also, respondents older than 25 years significantly use more contraceptives $(39.2 \%$ vrs $2.7 \%$ to $16.7 \%$, $\mathrm{p}<0.003)$ than younger respondents. Again, married respondents use contraceptives significantly more than the unmarried ones $(100.0 \%$ vrs $6.6 \%$ to $24.7 \%, \mathrm{p}<0.0001$ ) (Table 5) shows the association between respondents' usage of contraceptives and their socio-demographic characteristics.

Table 5: Relationship between the respondents' contraceptive use and their socio-demographic characteristics.

\begin{tabular}{|c|c|c|c|}
\hline Variable & Subgroup & Number who used contraceptives (\%) & p-value \\
\hline Sex & Female $(\mathrm{n}=187)$ & $32(17.1 \%)$ & 0.537 \\
\hline & Male $(\mathrm{n}=189)$ & $37(19.6 \%)$ & 0.581 \\
\hline Religious affiliation & Islam $(\mathrm{n}=123)$ & $21(17.1 \%)$ & $<4(19.1 \%)$ \\
\hline Age & Christianity $(\mathrm{n}=251)$ & $1(2.7 \%)$ & $<.054$ \\
\hline & $<20(\mathrm{n}=37)$ & $48(16.7 \%)$ & $<0.003^{*}$ \\
\hline & $20-25(\mathrm{n}=288)$ & $20(39.2 \%)$ & $<0.0001^{*}$ \\
\hline Relationship status & $>25(\mathrm{n}=51)$ & $12(6.6 \%)$ & $<0.0001^{*}$ \\
\hline & Single and in no relationship (n= & $39(24.7 \%)$ & $<0.0001^{*}$ \\
\hline & Single and in relationship (n=158) & $18(100.0 \%)$ & $0.033^{*}$ \\
\hline
\end{tabular}

*Statistically significant

Table 6: Predictors of contraceptive use in students in the previous 12 months.

\begin{tabular}{|c|c|c|c|c|c|}
\hline \multicolumn{6}{|c|}{ Usage of Contraceptive Methods } \\
\hline Variable & Characteristics & $\mathrm{p}$ value & $\begin{array}{l}\text { Crude Odd ratio }(95 \% \\
\text { CI) }\end{array}$ & $\mathrm{p}$ value & $\begin{array}{l}\text { Adjusted Odd ratio } \\
\quad(95 \% \mathrm{CI})\end{array}$ \\
\hline \multirow[t]{2}{*}{ Sex } & Female $(\mathrm{n}=187)$ & 0.537 & 1 & $0.037^{*}$ & 1 \\
\hline & Male (n=189) & & $1.179(0.70-1.99)$ & & $1.95(1.04-3.67)$ \\
\hline \multirow[t]{2}{*}{ Religious affiliation } & Islam (n = 123) & 0.581 & 1 & 0.439 & 1 \\
\hline & Christianity $(\mathrm{n}=251)$ & & $1.171(0.67-2.06)$ & & $1.28(0.68-2.40)$ \\
\hline \multirow[t]{3}{*}{ Age } & $<20(\mathrm{n}=37)$ & $<0.0001^{*}$ & 1 & 0.407 & 1 \\
\hline & $20-25(n=288)$ & 0.054 & $7.20(0.96-53.79)$ & 0.181 & $4.03(0.52-31.05)$ \\
\hline & $>25(n=51)$ & $<0.003^{*}$ & $23.23(2.95-183.14)$ & 0.211 & $4.18(0.44-39.30)$ \\
\hline \multirow[t]{3}{*}{ Relationship status } & $\begin{array}{l}\text { Single and in no } \\
\text { relationship }(\mathrm{n}=182)\end{array}$ & $<0.0001^{*}$ & 1 & $<0.0001^{*}$ & 1 \\
\hline & $\begin{array}{l}\text { Single and in } \\
\text { relationship }(\mathrm{n}=158)\end{array}$ & $<0.0001^{*}$ & $4.64(2.33-9.24)$ & $<0.0001^{*}$ & $5.36(2.60-11.07)$ \\
\hline & Married $(\mathrm{n}=18)$ & $<0.0001^{*}$ & $15.00(6.20-36.32)$ & $<0.0001^{*}$ & $10.48(4.81-56.49)$ \\
\hline \multirow[t]{2}{*}{$\begin{array}{l}\text { Locality of stay between } \\
\text { ages } 6 \text { and } 15 \text { years }\end{array}$} & Urban $(n=211)$ & & 1 & 0.267 & 1 \\
\hline & Rural (n = 96) & $0.033^{*}$ & $1.79(1.05-3.05)$ & & $1.41(0.77-2.61)$ \\
\hline
\end{tabular}

*Statistically significant

Results for the logistic regression analysis were used to assess the possible predictors that are associated with the use of contraceptives among the student population which is shown in (Table 6). Crude odds ratios showed that male respondents were almost $18 \%$ more likely to use contraceptives than their female colleagues (OR $=1.18 ; 95 \% \mathrm{CI}, 0.70-1.99$ ) and Christians almost $17 \%$ (OR $=1.171 ; 95 \% \mathrm{CI}, 0.67-2.06)$ more like to use contraceptives than their Moslem colleagues although the differences were not statistically significant. Crude odd results value showed that students who were more than 25 year old were 23 times more like 
to use contraceptive than those less than 20 years $(0 \mathrm{R}=23.23$; $95 \%, 2.95$ - 183.14; $\mathrm{p}=0.003$ ) while married students were 15 time more likely to use contraceptives than the single not in any relationship (OR = 15.00; 95\% CI, $6.20-36.32 ; \mathrm{p}<0.0001)$. Students who grew up in rural areas of Ghana also were 1.79 times likely to use contraceptives than their urban colleagues (OR $=1.79 ; 95 \% \mathrm{CI}$, $1.05-3.05 ; p=0.033$ ). After adjusting all variable with all the sociodemographic characteristics, only relationship status remained statistically associated with contraceptive use (AOR $=10.48 ; 95 \%$ CI, 4.81 - 56.49; $p<0.0001$ ) while sex of the respondents which before adjustment was not statistically significant (AOR = 1.95; 95\% CI, 1.04 - 3.67; $\mathrm{p}=0.037$ ) (Table 6).

\section{Discussion}

Adolescence heralds the desire for sexual relationship which may lead to various undesirable consequences including unwanted pregnancies and sexually transmitted diseases. Contraception is the surest way out of the health and economic burden brought upon countries by unwanted pregnancies and to some extent sexually transmitted infections such as HIV [1,3]. Health professionals are no doubt indispensable in meeting the contraceptive needs of nations. Although not yet qualified, health profession trainees in their communities are constantly being contacted to provide information on reproductive health which makes it imperative that they possess adequate knowledge on contraceptive methods. Students in the current study showed a good awareness level of contraceptive methods with almost $98 \%$ able to list at least one male or female contraceptive methods; similar to a report in Nigeria where $95 \%$ of students correctly listed at least one contraceptive [17]. This study however showed that students were more aware of female contraceptive methods than that of the males. The reasons could be due to availability of more female contraceptive methods than those of the males [18]. This study found that students' age, programme of study, and their relationship or marital status were all significantly associated with their level of awareness of both male and female contraceptive methods. A possible reason for the effect of age on level of awareness of contraceptive methods is that as the student gets older, the chance of entering into relationships with the opposite sex increases which invariably could get them involved in sexual intercourse. To prevent unwanted pregnancies, these students procure contraceptives which then possibly increase their awareness level of the various contraceptive methods.

Marital status significantly increasing students' knowledge on and use of contraceptive methods could be because almost a tenth of the students were married and two-fifth was in relationship. Such persons who would not want pregnancy to disrupt their studies make effort to acquire knowledge on the available contraceptive methods and subsequently use them. This study also found awareness level on contraceptive methods being significantly associated with the programme of study of the students. Midwifery students were the most aware with the Community Nutrition students being the most deficient in awareness of both male and female contraceptive methods. The differences in the level of awareness among the students of the various programmes with those pursuing first degree in midwifery being most aware could be attributed to several factors. In the first place, the midwifery class had the highest number of married students most of who are older than 25 years. Again, the midwifery classes have among them, practicing midwives who had enrolled to pursue their first degree in midwifery in the university. In Ghana, midwives play key roles in the family planning clinics in most health facilities hence it is understandable that the midwifery class with these practicing midwives had the best level of awareness on contraceptive methods in this study [19]. This study found more male students almost two times likely to significantly use contraceptives than their female colleagues. Significant association was found between males and their patronage of contraceptive methods; in similar surveys conducted in southern and central parts of Ghana and also in Botswana [20-22].

Meanwhile [23] in a study in Turkey found more females using contraceptives than males [23]. The male condom just as reported in several previous studies $[17,20,23,24]$ was the most commonly used contraceptive among the males in this study who had used any form of contraception within the previous twelve months. The high patronage of male condoms could be attributable to various factors including the high level of advertisement of various brands of condom in the media in Ghana. Also, there is no sex education without any education on condom use as it is being widely promoted to manage the HIV/AIDS pandemic [25-26]. In the case of the female students, the emergency contraceptive pill, Levonorgestrel under the brand name, Postinor 2 was the most widely used contraceptive. The use of Postinor 2 should be of public health concern since it shows that in this study, most females who are sexually active were indulging in risky sexual intercourse which exposes them to sexually transmitted infections [27]. reported that the oral contraceptive pill was the most used contraceptive among female undergraduate students in University of New Hampshire [27].

Although the oral contraceptive pill was not the most used female contraceptive in this study; it was the best known just as reported in other studies in Nigeria [17,25-26]. In Ghana, the high level of advertisement of female contraceptives in the media and their availability in both private and public health facilities could account for the high knowledge about oral contraceptive pills [18]. The level of patronage of contraception among university students for males and females were $69.8 \%$ and $71.9 \%$ respectively in Turkey but $80.3 \%$ and $73.4 \%$ in Botswana [22-23]. The relatively higher average contraceptive usage of $33.7 \%$ recorded in this study which is more than the national contraceptive prevalence rate of $25.6 \%$ is encouraging. This higher than national average contraceptive usage among these health profession trainees could be due to greater knowledge they possess and a significant number of them also being married. According to the 2014 Ghana Health and Demographic Survey (GHDS) report published by the Ghana Statistical Service (2015) the median age of first sexual intercourse in Ghana for persons between 25 to 49 years were 19.8 and 18.4 years for men and women respectively [28]. Since $90.1 \%$ of students were above 20 years, it is mostly likely that a lot more than 69 (18.4\%) may be sexually active. For barely $33.7 \%$ of even the married or those in relationship to admit using any form of contraceptive while colleague university students in Turkey and 
Bostwana had contraceptive patronage rate above $70 \%$ should be a matter of concern for administrator of universities in Ghana.

Getting to know students who were sexually active in this study was not possible because during piloting of the questionnaire, a question to know the age of sexual debut and sexuality status was not well answered hence its deletion from the final questionnaire. Another limitation that could affect the results obtained from this study is the use of self-administered questionnaire rather than interviewing which makes verification of the answers provided by the students difficult. Again, this study was undertaken among students of one of the campuses of the University for Development Studies. The results of this study cannot therefore be generalized for all university students in Ghana. This requires that a future study among students from all Ghanaian universities in the country so as to give a wider application of the findings. The strength of this study however was the application of a simple random sampling method in the selection of the study population which invariably minimized the biases in the selection of the students.

\section{Conclusion}

The awareness level of students pursuing clinically related courses on contraceptive methods is good but midwifery students, older students, and those in relationship or married possessed a significantly better level of awareness than their other colleagues. Condom was the most used contraceptive by the male students but most female students prefer using the emergency contraceptive, Postinor2. Although being married, growing up in rural Ghana and being older than 25 years were significantly associated with contraceptive use, the main predictors of contraceptive use in this study were being a male student and also being married.

\section{References}

1. Peipert JF, Madden T, Allsworth JE, Secura GM (2012) Preventing unintended pregnancies by providing no-cost contraception. Obstetrics and gynecology 120(6): 1291-1297.

2. Miller G (2010) Contraception as development? new evidence from family planning in colombia*. The Economic Journal 120(545): 709-736.

3. Tsui AO, McDonald-Mosley R, Burke AE (2010) Family planning and the burden of unintended pregnancies. Epidemiologic reviews 32(1): 152174.

4. Santelli JS, Lindberg LD, Finer LB, Singh S (2007) Explaining recent declines in adolescent pregnancy in the United States: the contribution of abstinence and improved contraceptive use. American Journal of Public Health 97(1): 150-156.

5. Ahmed S, Li Q, Liu L, Tsui AO (2012) Maternal deaths averted by contraceptive use: an analysis of 172 countries. The Lancet 380(9837): 111-125.

6. Cleland J, Conde-Agudelo A, Peterson H, Ross J, Tsui A (2012) Contraception and health. The Lancet 380(9837): 149-156.

7. Kavanaugh ML, Anderson RM (2013) Contraception and beyond: The health benefits of services provided at family planning centers.

8. (2013) United Nations Department of Economic and Social Affairs, Population Division.

9. Ezeh AC, Bongaarts J, Mberu B (2012) Global population trends and policy options. The Lancet 380(9837): 142-148.

10. (2011) National Population Council - Ghana. Ghana population stabilization report. Accra.
11. Sedgh G, Hussain R, Bankole A, Singh S (2007) Women with an unmet need for contraception in developing countries and their reasons for not using a method. Occasional report 37: 5-40.

12.Hindin MJ, Mc Gough LJ, Adanu RM (2014) Misperceptions, misinformation and myths about modern contraceptive use in Ghana. Journal of Family Planning and Reproductive Health Care 40(1): 30-35.

13. Williamson LM, Parkes A, Wight D, Petticrew M, Hart GJ (2009) Limits to modern contraceptive use among young women in developing countries: a systematic review of qualitative research. Reprod Health 6(3): 1-12.

14. Stanback J, Twum-Baah KA (2001) Why do family planning providers restrict access to services? An examination in Ghana. International Family Planning Perspectives 27(1): 37-41.

15. Koenig MA, Ahmed S, Hossain MB (2003) The impact of quality of care on contraceptive use: evidence from longitudinal data from rural Bangladesh. Frontiers in Reproductive Health, Population Council 2003.

16. (2015) United Nations, Department of Economic and Social Affairs, Population Division. World Contraceptive Use 2015.

17.Zaggi, Hilary Y (2014) Contraceptive knowledge and practices among students in federal polytechnic Kaduna, Nigeria: an exploratory study (Doctoral dissertation, Stellenbosch: Stellenbosch University).

18. Adjei KK, Laar AK, Narh CT, Abdulai MA, Newton S, et al. (2015) A comparative study on the availability of modern contraceptives in public and private health facilities in a peri-urban community in Ghana. Reproductive health 12(1): 1.

19. Prosser M, Sonneveldt E, Hamilton M, Menotti E, Davis P (2006) The emerging midwifery crisis in Ghana: mapping of midwives and service availability highlights gaps in maternal care. United States Aid for International Development.

20. Agyei WK, Biritwum RB, Ashitey AG, Hill RB (2000) Sexual behaviour and contraception among unmarried adolescents and young adults in Greater Accra and Eastern regions of Ghana. Journal of biosocial Science 32(4): 495-512.

21. Geelhoed DW, Nayembil D, Asare K, Van Leeuwen JH, Van Roosmalen J (2002) Contraception and induced abortion in rural Ghana. Tropical Medicine \& International Health 7(8): 708-716.

22. Hoque ME, Ntsipe T, Mokgatle-Nthabu M (2013) Awareness and practices of contraceptive use among university students in Botswana. SAHARA-J 10(2): 83-88.

23. Aras S, Orcin E, Ozan S, Semin S (2007) Sexual behaviours and contraception among university students in Turkey. Journal of Biosocial Science 39(1): 121-135.

24. Idonije BO, Oluba OM, Otamere HO (2011) A study on knowledge, attitude and practice of contraception among secondary school students in Ekpoma, Nigeria. JPCS (2): 22-27.

25. Tayo A, Akinola O, Babatunde A, Adewunmi A, Osinusi D, Shittu L (2011) Contraceptive knowledge and usage amongst female secondary school students in Lagos, Southwest Nigeria. Journal of Public health and Epidemiology 3(1): 34-37.

26. AO DC, Abah So, Abejegah C, Asalu OB, Oriaifo B (2014) Contraception among Tertiary Students: Knowledge, use and Behaviour of Female Undergraduates in Edo State, Nigeria. Global Journal of Medical Research $14(2)$.

27. Heisler K, Van Eron DM (2012) A descriptive study of undergraduate contraceptive attitudes among students at the University of $\mathrm{New}$ Hampshire. Honors Theses, UK.

28. (2014) Ghana Statistical Service (GSS), Ghana Health Service (GHS), and ICF International. Ghana Demographic and Health Survey 2014. Rockville, Maryland: GSS, GHS, and ICF International, USA. 
ISSN: 2574-1241

DOI: 10.26717/BJSTR.2018.07.001435

Evans Paul Kwame Ameade1. Biomed J Sci \& Tech Res

(C) This work is licensed under Creative

Submission Link: https://biomedres.us/submit-manuscript.php

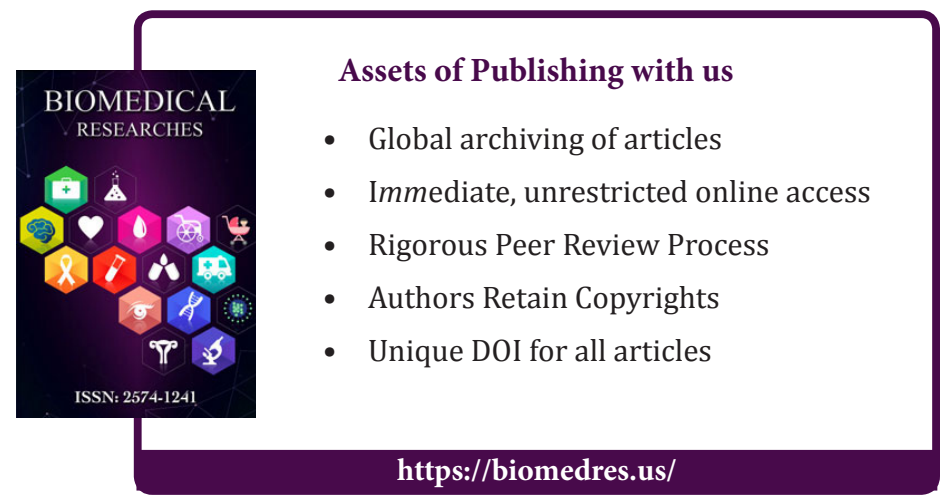

